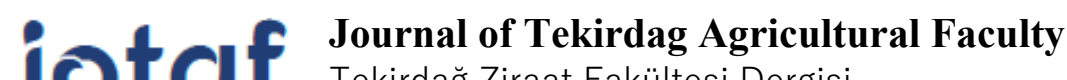 \\ Tekirdağ Ziraat Fakültesi Dergisi
}

\section{Determination of Commercially Available Biogas Production Capacity and Effects on Methane Capture in Tekirdă̆ Province}

\author{
Tekirdağ İlinde Ticari Olarak Kullanılabilir Biyogaz Üretim Kapasitesinin ve Metan \\ Tutumuna Etkilerinin Saptanmas1
}

\section{Birol KAYIŞ̧OĞLU ${ }^{1 *}$, Simge GÖNCÜ ${ }^{2}$}

\begin{abstract}
This research was carried out in farms which have 100 and more cows with commercial biogas production capacity, in 2019 in Tekirdağ. This is because it is stated that if the livestock enterprises have at least 100 animals, biogas production can be realized economically. The distribution and number of farms with this feature in districts were provided from Tekirdağ Food, Agriculture and Livestock Provincial Directorate. Biogas is generally used by converting it to heat and electrical energy. While it is used mostly for heating purposes in small farms, electricity and heat energy are provided in CHP units in large farms. Total methane production potential and energy value were calculated as $22466 \mathrm{Nm}^{3} \mathrm{day}^{-1}$ and $81756.4 \mathrm{MWhyear}^{-1}$, respectively. The highest methane production potential and energy value is in Muratlı district and the least is in Çerkezköy district. It was determined that

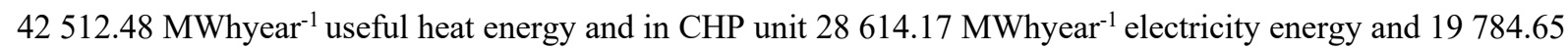
MWhyear ${ }^{-1}$ additional heat energy could be obtained from methane produced by anaerobic fermentation. It is determined that 19067.56 tons $\mathrm{CO}_{2}$ eyear ${ }^{-1}$ of methane will be released if the manure is stored outdoors. It was determined that methane emission could be reduced by 1087.13 tons $\mathrm{CO}_{2 \mathrm{eyear}}{ }^{-1}$ if the nitrogen was used in fermentation residues instead of the chemical fertilizer. Total methane retention in the use of methane for heat

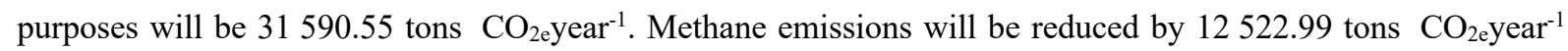
when used for heat purposes, than the conditions in which the manure is stored outdoors. When methane is used in the CHP unit to provide electricity and heat energy, total methane retention is calculated as 38467.6 tons $\mathrm{CO}_{2 \text { eyear }}{ }^{-1}$, and the decrease in methane emission is calculated as 19400 tons $\mathrm{CO}_{2 \mathrm{e} y e a r^{-1}}$. In animal husbandry enterprises that are located in Tekirdağ and are commercially producing, evaluation of manure without long-term storage by means of anaerobic digestion is important in terms of meeting of the energy requirement and reducing methane emission and the government should encourage enterprises in this regard.
\end{abstract}

Keywords: Biogas, anaerobic digestion, methane emission, methane capture, emission factor

\section{Özet}

Bu araştırma, 2019 yılında Tekirdağ ilinde ticari anlamda biyogaz üretimi kapasitesine sahip 100 ve daha fazla büyükbaş hayvan bulunan işletmelerde yürütülmüştür. Bunun nedeni hayvancılık işletmelerinin en az 100 hayvana sahip olmaları durumunda, biyogaz üretiminin ekonomik olarak gerçekleşebileceğinin belirtilmesidir. Bu

\footnotetext{
$1 *$ Sorumlu Yazar/Corresponding Author: Birol KAYİ̧̧ĞLU, Department of Agricultural Faculty Biosystem Engineering, Tekirdağ Namık Kemal University, 59030 Tekirda $\breve{g} / T U R K E Y$. E-Mail: bkayisoglu@nku.edu.tr (iD)OrcID: 0000-0002-2885-3174

2 Simge GÖNCÜ, Department of Agricultural Faculty Biosystem Engineering, Tekirdağ Namık Kemal University, 59030 Tekirdağ/TURKEY. E-Mail: simgeozgur93@gmail.com (iD)OrcID: 0000-0002-8914-8938

Atıf/Citation: Kayisoglu B., Goncu S., Determination of Commercially Available Biogas Production Capacity and Effects on Methane Capture in Tekirdağ Province. Tekirdăg Ziraat Fakültesi Dergisi, 17 (3), 445-455

*Bu çalışma Yüksek Lisans tezinden özetlenmiştir.

CBu çalışma Tekirdağ Namık Kemal Üniversitesi tarafından Creative Commons Lisansı (https://creativecommons.org/licenses/by-nc/4.0/)

kapsamında yayınlanmıştır. Tekirdă̆ 2020
} 
Determination of commercially available biogas production capacity and effects on methane capture in Tekirdağ province özellikteki işletmelerin ilçelere göre dağılımları ve sayıları, Tekirdağ Gıda Tarım ve Hayvancılık il müdürlüğünden sağlanmıştır. Biyogaz genel olarak 1sı ve elektrik enerjisine dönüştürülerek kullanılmaktadır. Küçük işletmelerde daha çok 1sı amaçlı kullanılırken büyük işletmelerde ise CHP ünitelerinde elektrik ve isı enerjisi sağlanmaktadır. Toplam metan üretim potansiyeli ve enerji değeri sırasıly $22466 \mathrm{Nm}^{3}$ gün ${ }^{-1}$ ve $81756.4 \mathrm{MWhyll}^{-1}$ olarak hesaplanmıştır. En fazla metan üretim potansiyeli ve enerji değeri Muratlı ilçesinde, en az ise Çerkezköy ilçesindedir. Aneorobik fermantasyon ile üretilen metandan $42512.48 \mathrm{MWhyl}^{-1}$ yararlı 1sı enerjisi, CHP ünitesinde $28614.17 \mathrm{MWhyl}^{-1}$ elektrik enerjisi ve $19784.65 \mathrm{MWhyll}^{-1}$ ek 1s1 enerjisi elde edilebileceği saptanmıştır. Gübrenin açıkta depolanması halinde 19067.56 ton $\mathrm{CO}_{2 \mathrm{e}} \mathrm{y} 11^{-1}$ metan salınımı olacağı belirlenmiştir. Fermantasyon artıklarında bulunan azotun kimyasal gübre olarak kullanılması durumunda metan emisyonunun 1087.13 ton $\mathrm{CO}_{2 \mathrm{ey}} \mathrm{l}^{-1}$ azaltılabileceği tespit edilmiştir. Metanın $1 \mathrm{~s} 1$ amaçlı kullanılmasında toplam metan tutumu 31590.55 ton $\mathrm{CO}_{2 e} \mathrm{e}_{1}{ }^{-1}$ olacaktır. Metan emisyonu. 1sı amaçlı kullanımda gübrenin açıkta depolandığ koşullara göre 12522.99 ton $\mathrm{CO}_{2 \mathrm{e}} \mathrm{yl}^{-1}$ azalacaktır. Metanın $\mathrm{CHP}$ ünitesinde elektrik ve 1S1 enerjisi sağlamak için kullanılması durumunda, toplam metan tutumu 38467.6 ton $\mathrm{CO}_{2 \mathrm{e}} \mathrm{y} 11^{-1}$, metan salınımındaki azalma 19400 ton $\mathrm{CO}_{2 \mathrm{e}} \mathrm{yl}^{-1}$ olarak hesaplanmıştır. Tekirdağ' da bulunan ve ticari olarak üretim yapan hayvancilık işletmelerinde gübrenin uzun süre depolanmadan, anaerobik sindirim yoluyla değerlendirilmesi, hem enerji gereksiniminin bir kısmının karşılanması, hem de metan emisyonunun azaltılması açısından önemlidir ve devletin bu konuda işletmeleri teşvik etmesi gerekmektedir.

Anahtar Kelimeler: Biyogaz, anaerobik sindirim, metan salınım, metan tutumu, emisyon faktörü 


\section{Introduction}

Biomass has an important potential as a renewable energy source. It can be converted into different types of energy by burning directly or by using thermo-chemical and biochemical conversion methods. Biogas is a combustible gas obtained by anaerobic digestion, which is one of the biochemical conversion methods, containing about $60 \%$ methane $\left(\mathrm{CH}_{4}\right)$ and about $40 \% \mathrm{CO}_{2}$. The specific energy value is between $5-7.5 \mathrm{KWhNm}^{-3}$ depending on the $\mathrm{CH}_{4}$ ratio in the content of the biogas. The density of the biogas is about $1.22 \mathrm{kgNm}^{-3}$ (Rutz, 2015).

The energy value of biogas produced in the world in 2014 is around $352780 \mathrm{GWh}$. The most biogas in the world is produced in China with an energy value of $91490 \mathrm{kWhyear}^{-1}$. This country is followed by Germany with 86460 GWhyear $^{-1}$, America with 73830 GWhyear $^{-1}$ and Russia with 32240 GWhyear $^{-1}$ (Anonymous, 2017). The energy value of biogas production in our country was around $2706 \mathrm{GWhyear}^{-1}$ in 2014 . Considering the production in the world, it is seen that the biogas production in our country is quite low. Only $10 \%$ of technical biogas potential of Turkey is evaluated (Anonymous, 2019a).

Especially, the emission of methane, which occurs as a result of animal production, is an important factor in the increase of greenhouse gas. Animal production causes $18 \%$ of the greenhouse gas emissions in the world. The production of animal manure and urine, which is the source of this emission, is around 13 billion tons per year in the world (Harkin, 1997). Capture of the methane of manure by biogas production plays an important role in the reduction of methane emissions from agricultural and urban wastes as well as energy recovery.

The simplest method of obtaining heat energy from biogas is to directly burn it in boiler systems. The efficiency of the biogas burning process varies between $75-85 \%$. Boiler systems used to burn natural gas can also be used in biogas combustion by changing fuel-air mixture ratios. However, since biogas has lower energy content, higher flow rate is required. Therefore, the combustion unit also needs to be modified. Since low quality biogas is burned in boiler systems, the operating temperatures should be above the dew point to prevent condensation (Krich et al, 2005).

CHP (Cogeneration-combined Heat and Power) systems are used to obtain electricity and additional heat energy from biogas. While electrical energy is obtained with the generator connected to the gas engines used in these systems, the resulting heat energy is transferred to a fluid or air with the help of heat exchangers in the engine and exhaust outlet. In modern CHP units, heat losses are around 10-15\%, electrical energy efficiency is 30-40\%, and heat energy efficiency is around 40-50\%. The overall efficiency of the CHP system can be $80 \%$ and above (Dueblein and Stainhauser, 2011). In addition, Recebli et al (2015) stated that if biogas is used for heat purposes, a gain of $\$ 0.35 / \mathrm{m}^{3}$ can be achieved compared to natural gas.

In recent years, it has become common to remove $\mathrm{CO}_{2}$ from biogas and to obtain biomethane. In this improvement process, the energy value of the product is increased, and its transportation and storage become easier. In addition, it is possible to use it in gas engines or vehicles directly or with natural gas without any additional treatment. Biomethane is also used as a raw material in the chemical industry (Beil and Beyrich, 2013).

Biogas is a renewable energy source and is increasingly important in terms of providing sustainable energy. As a greenhouse gas, methane is 25 times stronger than $\mathrm{CO}_{2}$. Therefore, in addition to the energy value of the biogas obtained in the biogas production process, methane capture is also important in terms of environmental effects. As a result of long-term storage of manure, $20-45 \%$ of the total methane potential is mixed into the atmosphere as a greenhouse gas emission (Dumont et al., 2013). If biomethane is used instead of fuel oil to obtain heat and electrical energy, $0.269 \mathrm{~kg} \mathrm{CO} 2 \mathrm{e} / \mathrm{kWh}$ and $0.454 \mathrm{~kg} \mathrm{CO}_{2} \mathrm{e} / \mathrm{kWh}$ methane capture are provided, respectively. Also, $6.172 \mathrm{~kg} \mathrm{CO}_{2} \mathrm{e} / \mathrm{kg}$ methane attitude can be achieved if nitrogen in fermentation wastes is used instead of chemical nitrogen fertilizer (DEEC, 2013; Frost and Gilkinson, 2010).

In a study conducted by Yaldız and Sözer (2005), it was understood that 100 animals for cattle, 150000 for chicken, 2000 for sheep and 5000 for turkey were economical size for biogas plants. In this study, it was aimed to determine the commercially biogas production potential from cattle manure in Tekirdağ province and to determine its effects on methane capture if this potential is used as an energy source. 


\section{Materials and Methods}

\subsection{Determination of the number of cattle farms in the region}

$25 \%$ of the gross production value of Tekirdağ province is due to animal production. There has been a significant increase in the number of bovine animals in the region in recent years (Anonymous, 2019b). The research was carried out by identifying bovine farms with 100 and more animals in Tekirdağ. $25 \%$ of the gross production value of Tekirdağ province is due to animal production.

\subsection{Determination of methane production potential and energy value}

The coefficients used to determine the methane production potential are given in Table 1. The value of $n$ in Table 1 means the number of animals.

Table 1. Coefficients used in the calculation of methane production potential (Lukahurst ve Bywater, 2015)

\begin{tabular}{lcc}
\hline & Value & Unit \\
\hline Production of Liquid cattle manure (PLM) & $55 \frac{\mathrm{kg}}{\text { day-animal }} * \mathrm{n}$ & $\mathrm{kgday}^{-1}$ \\
Total Solids (TS) & $\% 13.9$ PLM & kgday $^{-1}$ \\
Volatile Solids (VS) & $\% 11.62$ PLM or \%83 TS & kgday $^{-1}$ \\
Methane Production (MP) & $0.15 \frac{\mathrm{Nm}^{3}}{\mathrm{~kg}-\mathrm{VS}} * \mathrm{VS}$ & $\mathrm{Nm}^{3} \mathrm{day}^{-1}$ \\
Specific Energy of Methane (SEM) & 9.97 & $\mathrm{kWhNm}^{-3}$ \\
Total Energy Value of Methane (TEV) & MP*SEM & $\mathrm{kWhday}^{-1}$ \\
\hline
\end{tabular}

\subsection{Determination of useful heat energy that can be obtained from methane}

It is assumed that $48 \%$ of the produced methane is used for heating the reactor, and the remaining $52 \%$ is used as useful energy (Lukahurst and Bywater, 2015). Useful potential for heat purposes of the methane was calculated with the help of the following equation:

$$
E P_{\text {heat }}=0.52 * T E V
$$

Where; $E P_{\text {heat }}\left(\mathrm{kWhday}^{-1}\right)$ is the useful heat energy potential of the methane.

\subsection{Determination of the usage energy potential of the methane in the CHP unit}

In use in the CHP unit, $90 \%$ of the energy obtained from methane turns into useful energy. It is accepted that $35 \%$ of this useful energy turns into electrical energy and $55 \%$ of it turns into heat energy (Rutz, 2015). It is assumed that $56 \%$ of the heat energy produced in the CHP unit is used for reactor heating (Lukahurst and Bywater, 2015).

The electrical energy potential of the methane is calculated with the formula below:

$E P_{\text {elk }}=0.35 * T E V$

Where; $E P_{\text {elk }}\left(\mathrm{kWhday}^{-1}\right)$ is the electrical energy potential of the methane in CHP unit.

The useful part of the heat energy generated in the CHP unit has been found with the help of the following equation:

$E P_{C H P, \text { heat }}=0.44 *(0.55 * T E V)$

Where; $E P_{C H P, \text { heat }}\left(\mathrm{kWhday}^{-1}\right)$ is the useful heat energy potential of the methane in CHP unit. 


\subsection{Methane emission and $\mathrm{CO}_{2}$ equivalent in long term storage of the manure}

The methane emission and $\mathrm{CO}_{2}$ equivalent occurring in long-term storage of the manure are calculated by taking into account the values given in Table 2.

Table 2. Methane release in long-term storage (Lukahurst ve Bywater, 2015)

\begin{tabular}{lcc}
\hline & Value & Unit \\
\hline Methane emission in long-term storage $\left(\mathrm{MEL}_{\mathrm{v}}\right)$ & $\% 13 \mathrm{MP}$ & $\mathrm{Nm}^{3}$ day $^{-1}$ \\
$\begin{array}{l}\text { Methane release in long-term storage }(\mathrm{MEL} \\
\mathrm{CO}_{2} \text { equivalent of methane emission in long-term }\end{array}$ & $0.715474 \mathrm{~kg} / \mathrm{Nm}^{3 *} \mathrm{MEL}_{\mathrm{v}}$ & $\mathrm{kgday}^{-1}$ \\
storage $\left(\mathrm{MELCO}_{2 \mathrm{e}}\right)$ & $25^{*} \mathrm{MEL}_{\mathrm{m}}$ & $\mathrm{kg} \mathrm{CO}_{2 \mathrm{e} \mathrm{day}^{-1}}$ \\
\hline
\end{tabular}

\subsection{Determination of the methane capture if methane is used instead of Fuel Oil}

As a result of converting the methane into heat and electrical energy, emission factors of $\mathrm{CO}_{2}$ equivalent of the methane capture are given in Table 3 .

Table 3. Emission reduction factors (DECC, 2013)

\begin{tabular}{lcc}
\hline \multicolumn{1}{c}{ Usage } & EF & Unit \\
\hline Heat energy & 0.269 & $\mathrm{~kg} \mathrm{CO}_{2 \mathrm{ekWh}} \mathrm{kg}^{-1}$ \\
Electrical energy & 0.454 & $\mathrm{~kg} \mathrm{CO}_{2 \mathrm{ekWh}}{ }^{-1}$ \\
\hline
\end{tabular}

$\mathrm{CO}_{2}$ equivalent of total methane capture when obtaining heat energy from the methane was found with the following formula:

$$
M C_{\text {heat }}=E F_{\text {heat }} * E P_{\text {heat }}
$$

Where; $M C_{\text {heat }}\left(\mathrm{Kg} \mathrm{CO}_{2 \mathrm{kWh}} \mathrm{kW}^{-1}\right)$ is the methane capture for using as heat energy, $E F_{\text {heat }}$ is the emission factor of methane capture for heat energy.

$\mathrm{CO}_{2}$ equivalent of total methane capture when usage of the methane in CHP system was found with the following formula:

$$
\begin{aligned}
& M C_{e l}=E F_{e l} * E P_{e l} \\
& M C_{C H P, \text { heat }}=E F_{\text {heat }} * E P_{C H P, \text { heat }}
\end{aligned}
$$

Where; $M C_{e l}$ and $M C_{C H P, \text { heat }}\left(\mathrm{Kg} \mathrm{CO}_{2 \mathrm{e}} \mathrm{day}^{-1}\right)$ are the methane capture for obtaining electrical energy and heat from the methane.

\subsection{Determination of the methane capture if the digested material is used instead of mineral fertilizer}

As a result of using digested materials as fertilizer, emission factors of $\mathrm{CO}_{2}$ equivalent of the methane capture are given in Table 4 (Frost and Gilkinson, 2010).

Table 4. Methane capture in using of digested material as fertilizer

\begin{tabular}{lcc}
\hline & Value & Unit \\
\hline The amount of nitrogen in the slurry (ANS) & $0.286 \frac{\mathrm{kg}}{\text { day }- \text { animal }} * \mathrm{n}$ & kgday $^{-1}$ \\
$\begin{array}{l}\text { Usable amount of nitrogen (UN) } \\
\text { Amount of nitrogen available as fertilizer in } \\
\text { digested material (FAM) }\end{array}$ & $0.36 \mathrm{ANS}$ & $\mathrm{kgday}^{-1}$ \\
$\mathrm{CO}_{2}$ equivalent of the methane capture $\left(\mathrm{MC}_{\text {fer }}\right)$ & $6.172 \frac{\mathrm{kg} \mathrm{CO}_{2 \mathrm{e}}}{\mathrm{kg}} * \mathrm{FAM}$ & $\mathrm{kgday}^{-1}$ \\
\hline
\end{tabular}




\subsection{Determination of the total methane capture}

The total methane capture in using of methane for obtaining heat energy was calculated as below:

$$
\sum M C_{\text {heat }}=M C_{\text {heat }}+M C_{\text {fer }}+M E L C O_{2 e}
$$

The total methane capture in using of methane in CHP unit was calculated as below:

$$
\sum M C_{c h p}=M C_{e l}+M C_{C H P, \text { heat }}+M C_{f e r}+M E L C O_{2 e}
$$

\section{Results and Discussion}

\subsection{Current status of farms with having 100 or more cattle in Tekirda $\breve{g}$ province}

The distribution of farms with 100 and more cattle number in Tekirdağ in early 2019 by districts is given in Table 5. There are 77 farms in the city. The highest number of farms is in Malkara district with 19 and the minimum number of farms is in Çerkezköy district with 4. The number of cattle is less than 200 in $55 \%$ of the farms (Tan, 2018). The total number of animals in these farmers is 23435.

\begin{tabular}{|c|c|c|c|c|c|c|}
\hline \multirow[b]{2}{*}{ DISTRICTS } & \multicolumn{4}{|c|}{ Cattle Number } & \multirow[b]{2}{*}{$\begin{array}{c}\text { FARM } \\
\text { NUMBER }\end{array}$} & \multirow[b]{2}{*}{$\begin{array}{r}\text { CATTLE } \\
\text { NUMBER }\end{array}$} \\
\hline & $\begin{array}{c}100>= \\
\text { and } \\
<200\end{array}$ & $\begin{array}{c}200>= \\
\text { and } \\
<300\end{array}$ & $\begin{array}{c}300>= \\
\text { and } \\
<400\end{array}$ & $400<=$ & & \\
\hline Çerkezköy & 4 & 0 & 0 & 0 & 4 & 631 \\
\hline Çorlu & 4 & 4 & 0 & 1 & 9 & 1913 \\
\hline Ergene & 5 & 2 & 0 & 0 & 7 & 1104 \\
\hline Hayrabolu & 7 & 1 & 0 & 1 & 9 & 3153 \\
\hline Kapaklı & 6 & 0 & 1 & 0 & 7 & 1036 \\
\hline Malkara & 16 & 0 & 2 & 1 & 19 & 3416 \\
\hline Marmaraereğlisi & 3 & 0 & 1 & 1 & 5 & 1214 \\
\hline Muratlı & 4 & 0 & 0 & 1 & 5 & 7909 \\
\hline Saray & 4 & 2 & 0 & 0 & 6 & 1061 \\
\hline Süleymanpaşa & 2 & 1 & 2 & 1 & 6 & 1998 \\
\hline TOTAL & 55 & 10 & 6 & 6 & 77 & 23435 \\
\hline
\end{tabular}

Table 5. Distribution of farms and cattle number with more than 100 animals in Tekirdăg by districts

\subsection{Methane production potential and energy value}

Distribution of liquid manure, organic solid and methane production potentials and energy values by districts are given in Table 6. There is a total of 1288.9 tonsday $^{-1}$ liquid fertilizer and 149.8 tonsday $^{-1}$ organic solid matter productions in the city. The methane production potential was found to be $22466 \mathrm{Nm}^{3} \mathrm{day}^{-1}$. The energy value of the methane in biogas is $223.99 \mathrm{MWhday}^{-1}$ (Tan,2018). It is observed that there is a potential to provide 81756.4 MWh of energy in one year from the methane production in Tekirda $\breve{g}$ province. 
JOTAF/ Journal of Tekirdag Agricultural Faculty, 2020, 17(3)

Table 6. Methane production potential and energy value

\begin{tabular}{|c|c|c|c|c|c|}
\hline DISTRICT & $\begin{array}{c}\text { PLM } \\
\text { (tonsday }^{-1} \text { ) }\end{array}$ & $\begin{array}{c}\text { VS } \\
\left.\text { (tonsday }^{-1}\right)\end{array}$ & $\begin{array}{c}\text { MP } \\
\left(\text { Nm }^{3} \text { day }^{-1}\right)\end{array}$ & $\begin{array}{c}\text { TEV } \\
\left(\text { MWhday }^{-1}\right)\end{array}$ & $\begin{array}{c}\text { TEV } \\
\left(\text { MWhyear }^{-1}\right)\end{array}$ \\
\hline Çerkezköy & 34.7 & 4.03 & 604.9 & 6.03 & 2201.0 \\
\hline Çorlu & 105.2 & 12.23 & 1833.9 & 18.28 & 6672.2 \\
\hline Ergene & 60.7 & 7.06 & 1058.3 & 10.55 & 3850.8 \\
\hline Hayrabolu & 173.4 & 20.15 & 3022.6 & 30.14 & 11001.1 \\
\hline Kapaklı & 57.0 & 6.62 & 993.2 & 9.90 & 3613.5 \\
\hline Malkara & 187.9 & 21.83 & 3274.7 & 32.65 & 11917.3 \\
\hline Marmaraereğlisi & 66.8 & 7.76 & 1163.8 & 11.60 & 4234.0 \\
\hline Muratlı & 435.0 & 50.55 & 7582.0 & 75.59 & 27590.4 \\
\hline Saray & 58.4 & 6.78 & 1017.1 & 10.14 & 3701.1 \\
\hline Süleymanpaşa & 109.9 & 12.77 & 1915.4 & 19.10 & 6971.5 \\
\hline TOTAL & 1288.9 & 149.77 & 22466.0 & 223.99 & 81756.4 \\
\hline
\end{tabular}

\subsection{Useful energy potential in the use of methane for heat}

The distribution of useful energy amounts to be obtained in the case of using methane to be produced with biogas produced in Tekirdağ for heat purposes is given in Table 7. There is a potential for $116.47 \mathrm{MWhday}^{-1}$ of energy use throughout the province in use for heat purposes. The annual potential is $42512.48 \mathrm{MWh}$.

Table 7. Useful heat energy potential of methane

\begin{tabular}{lrc}
\hline DISTRICTS & $\begin{array}{c}\text { EPheat } \\
\text { (MWhday }^{-1} \text { ) }\end{array}$ & $\begin{array}{c}\text { EPheat } \\
\text { (MWhyear }^{-1} \text { ) }\end{array}$ \\
\hline Çerkezköy & 3.14 & 1144.67 \\
Çorlu & 9.51 & 3470.30 \\
Ergene & 5.49 & 2002.72 \\
Hayrabolu & 15.67 & 5719.73 \\
Kapaklı & 5.15 & 1879.37 \\
Malkara & 16.98 & 6196.83 \\
Marmaraereğlisi & 6.03 & 2202.27 \\
Muratlı & 39.31 & 14347.39 \\
Saray & 5.27 & 1924.72 \\
Süleymanpaşa & 9.93 & 3624.49 \\
TOTAL & $\mathbf{1 1 6 . 4 7}$ & $\mathbf{4 2} \mathbf{5 1 2 . 4 8}$ \\
\hline
\end{tabular}

\subsection{Useful energy potential in the use of methane in the CHP unit}

In case the methane production potential is used to obtain electrical energy in the CHP unit, there is 28614.17 MWhyear ${ }^{-1}$ electrical energy and $19784.65 \mathrm{MWhyear}^{-1}$ heat energy potential throughout the province. Total useful energy potential in the CHP unit is 48398.82 MWhyear $^{-1}$ (Table 8). 
Table 8. Useful energy potential in the CHP unit

\begin{tabular}{|c|c|c|c|c|}
\hline DISTRICTS & $\begin{array}{c}\text { EP }_{\mathrm{el}} \\
\left(\mathrm{MWhday}^{-1}\right)\end{array}$ & $\begin{array}{c}\text { EPCHP,heat } \\
\left(\text { MWhday }^{-1}\right)\end{array}$ & $\begin{array}{c}\text { Total } \\
\left(\text { MWhday }^{-1}\right)\end{array}$ & $\begin{array}{c}\text { Total } \\
\left.\text { (MWhday }^{-1}\right)\end{array}$ \\
\hline Çerkezköy & 2.11 & 1.46 & 3.57 & 1303.16 \\
\hline Çorlu & 6.40 & 4.42 & 10.82 & 3950.80 \\
\hline Ergene & 3.69 & 2.55 & 6.25 & 2280.02 \\
\hline Hayrabolu & 10.55 & 7.29 & 17.84 & 6511.69 \\
\hline Kapaklı & 3.47 & 2.40 & 5.86 & 2139.59 \\
\hline Malkara & 11.43 & 7.90 & 19.33 & 7054.85 \\
\hline Marmaraereğlisi & 4.06 & 2.81 & 6.87 & 2507.20 \\
\hline Muratlı & 26.46 & 18.29 & 44.75 & 16333.96 \\
\hline Saray & 3.55 & 2.45 & 6.00 & 2191.22 \\
\hline Süleymanpaşa & 6.68 & 4.62 & 11.31 & 4126.34 \\
\hline TOTAL & 78.39 & 54.20 & 132.60 & 48398.82 \\
\hline
\end{tabular}

\subsection{Methane release and $\mathrm{CO}_{2}$ equivalents in long-term storage of manure}

Methane emission values and their $\mathrm{CO}_{2}$ equivalents are given in Table 9 if the manure is stored for a long period of time without being evaluated as biogas. $2089.60 \mathrm{kgday}^{-1}$ of methane is emitted throughout the city and its $\mathrm{CO}_{2}$ equivalent is 52.24 tons $\mathrm{CO}_{2}$ day $^{-1}$. The $\mathrm{CO}_{2}$ equivalent of the annual methane emission is 19067.56 tons $\mathrm{CO}_{2 \mathrm{e}}$.

Table 9. Methane release in long-term storage of manure

\begin{tabular}{lrrr}
\hline DISTRICTS & $\begin{array}{c}\text { MELm } \\
\text { (kgday }^{-1} \text { ) }\end{array}$ & $\begin{array}{r}\text { MELCO }_{\mathbf{e}} \\
\text { (tonsday }^{-1} \text { ) }\end{array}$ & $\begin{array}{r}\text { MELCO }_{\mathbf{e}} \\
\text { (tonsyear }^{-1} \text { ) }\end{array}$ \\
\hline Çerkezköy & 56.26 & 1.41 & 513.40 \\
Çorlu & 170.57 & 4.26 & 1556.49 \\
Ergene & 98.44 & 2.46 & 898.25 \\
Hayrabolu & 281.14 & 7.03 & 2565.39 \\
Kapaklı & 92.38 & 2.31 & 842.93 \\
Malkara & 304.59 & 7.61 & 2779.38 \\
Marmaraereğlisi & 108.25 & 2.71 & 987.75 \\
Muratlı & 705.21 & 17.63 & 6435.05 \\
Saray & 94.60 & 2.37 & 863.27 \\
Süleymanpaşa & 178.15 & 4.45 & 1625.64 \\
TOTAL & $\mathbf{2 0 8 9 . 6 0}$ & $\mathbf{5 2 . 2 4}$ & $\mathbf{1 9 0 6 7 . 5 6}$ \\
\hline
\end{tabular}

\subsection{Methane capture in using of digested materials instead of mineral fertilizer}

If digested materials are evaluated as mineral fertilizers, $\mathrm{CO}_{2}$ equivalents of methane capture are given in Table 10. The amount of nitrogen of the liquid fertilizer (ANS) that emerges in the farms is $6702.4 \mathrm{kgday}^{-1}$. The amount of nitrogen (UN) suitable for use by bacteria in liquid fertilizer was calculated as $2412.9 \mathrm{kgday}^{-1}$, and the amount of nitrogen that could be used as mineral fertilizer (FAM) was $482.6 \mathrm{kgday}^{-1}$. If digested materials are evaluated as the mineral fertilizer, $2978.4 \mathrm{~kg} \mathrm{CO}_{2 \mathrm{eday}}{ }^{-1}$ and 1087.13 tons $\mathrm{CO}_{2 \mathrm{eyear}}{ }^{-1}$ methane capture will be provided. 
JOTAF/ Journal of Tekirdag Agricultural Faculty, 2020, 17(3)

Table 10. Methane capture in using of digested materials instead of mineral fertilizer

\begin{tabular}{|c|c|c|c|c|c|}
\hline DISTRICTS & $\begin{array}{c}\text { ANS } \\
\left(\mathrm{kgday}^{-1}\right)\end{array}$ & $\begin{array}{c}\text { UN } \\
\left(\text { kgday }^{-1}\right)\end{array}$ & $\begin{array}{c}\text { FAM } \\
\left(\text { kgday }^{-1}\right)\end{array}$ & $\begin{array}{c}\mathrm{MC}_{\text {fer }} \\
\left(\mathrm{kg} \mathrm{CO}_{2 \mathrm{eday}}{ }^{-1}\right)\end{array}$ & $\begin{array}{c}\mathrm{MC}_{\text {fer }} \\
\text { (tons } \mathrm{CO}_{2 \mathrm{eyear}}{ }^{-1} \text { ) }\end{array}$ \\
\hline Çerkezköy & 180.5 & 65.0 & 13.0 & 80.2 & 29.27 \\
\hline Çorlu & 547.1 & 197.0 & 39.4 & 243.1 & 88.74 \\
\hline Ergene & 315.7 & 113.7 & 22.7 & 140.3 & 51.21 \\
\hline Hayrabolu & 901.8 & 324.6 & 64.9 & 400.7 & 146.27 \\
\hline Kapaklı & 296.3 & 106.7 & 21.3 & 131.7 & 48.06 \\
\hline Malkara & 977.0 & 351.7 & 70.3 & 434.2 & 158.47 \\
\hline Marmaraereğlisi & 347.2 & 125.0 & 25.0 & 154.3 & 56.32 \\
\hline Muratlı & 2262.0 & 814.3 & 162.9 & 1005.2 & 366.89 \\
\hline Saray & 303.4 & 109.2 & 21.8 & 134.8 & 49.22 \\
\hline Süleymanpaşa & 571.4 & 205.7 & 41.1 & 253.9 & 92.69 \\
\hline TOTAL & 6702.4 & 2412.9 & 482.6 & 2978.4 & 1087.13 \\
\hline
\end{tabular}

\subsection{Total methane capture in the use of methane for heat}

The methane capture that will be provided if the methane in the biogas produced in the farms is used only for the purpose of obtaining heat energy is given in Table 11. In the conversion of methane to useful heat energy, a total of 86.55 tons $\mathrm{CO}_{2 \mathrm{eday}}{ }^{-1}$ and 31590.55 tons $\mathrm{CO}_{2 \mathrm{e}} \mathrm{year}^{-1}$ of methane capture are provided. In case the manure is not the long-term storage and converted into biogas in order to obtain heat energy by using instead of fuel oil, in addition to preventing the release of methane due to long-term storage, an additional 12522.99 tons $\mathrm{CO}_{2 \text { eyear }}$ ${ }^{1}$ of methane capture will be provided.

Table 11. Total methane capture in using of the methane in order to obtain the useful heat energy

\begin{tabular}{|c|c|c|c|c|c|}
\hline DISTRICTS & $\begin{array}{c}\text { MCheat } \\
(\text { tons CO } \\
\left.\text { day }^{-1}\right) \\
\end{array}$ & $\begin{array}{c}\mathrm{MC}_{\text {fer }} \\
\text { (tons } \mathrm{CO}_{2 \mathrm{e}} \\
\text { day }^{-1} \text { ) } \\
\end{array}$ & $\begin{array}{c}\mathrm{MELCO}_{2 \mathrm{e}} \\
\left(\text { tons } \mathrm{CO}_{2 \mathrm{e}}\right. \\
\left.\mathrm{day}^{-1}\right)\end{array}$ & $\begin{array}{c}\text { TOTAL } \\
\text { (tons CO } \mathrm{CO}_{2 \mathrm{e}} \\
\left.\text { day }^{-1}\right)\end{array}$ & $\begin{array}{c}\text { TOTAL } \\
\left.{\text { (tons } \mathrm{CO}_{2 \mathrm{e}}}_{\text {year }}\right)^{-1} \\
\end{array}$ \\
\hline Çerkezköy & 0.84 & 0.08 & 1.41 & 2.33 & 850.59 \\
\hline Çorlu & 2.56 & 0.24 & 4.26 & 7.07 & 2578.74 \\
\hline Ergene & 1.48 & 0.14 & 2.46 & 4.08 & 1488.20 \\
\hline Hayrabolu & 4.22 & 0.40 & 7.03 & 11.64 & 4250.27 \\
\hline Kapaklı & 1.39 & 0.13 & 2.31 & 3.83 & 1396.54 \\
\hline Malkara & 4.57 & 0.43 & 7.61 & 12.62 & 4604.79 \\
\hline Marmaraereğlisi & 1.62 & 0.15 & 2.71 & 4.48 & 1636.48 \\
\hline Muratlı & 10.57 & 1.01 & 17.63 & 29.21 & 10661.39 \\
\hline Saray & 1.42 & 0.13 & 2.37 & 3.92 & 1430.24 \\
\hline Süleymanpaşa & 2.67 & 0.25 & 4.45 & 7.38 & 2693.32 \\
\hline TOTAL & 31.33 & 2.98 & 52.24 & 86.55 & 31590.55 \\
\hline
\end{tabular}

\subsection{Total methane capture when using methane in the CHP unit}

In the case of using methane produced in the biogas unit in order to obtain electrical energy and additional heat in the CHP unit, a total of 35.59 tons $\mathrm{CO}_{2 \mathrm{e}} \mathrm{day}^{-1}$ methane capture for electrical energy and 14.58 tons $\mathrm{CO}_{2 \mathrm{eday}}{ }^{-1}$ methane capture at additional heat recovery can be provided (Table 12). Total methane capture in the CHP unit has been calculated as 105.39 tons $\mathrm{CO}_{2 \mathrm{eday}}{ }^{-1}$ and 38467.6 tons $\mathrm{CO}_{2 \mathrm{e}}$ year ${ }^{-1}$. In addition to preventing the release 
Determination of commercially available biogas production capacity and effects on methane capture in Tekirdağ province of methane due to long-term storage, an additional 19400 tons $\mathrm{CO}_{2 \text { eyear-1 }}{ }^{-1}$ of methane capture will be provided in the CHP unit.

Table 12. Total methane capture in using of the methane in the CHP unit

\begin{tabular}{|c|c|c|c|c|c|c|}
\hline DISTRICTS & $\begin{array}{c}\mathrm{MC}_{\mathrm{el}} \\
\left(\begin{array}{c}\text { tons } \mathrm{CO}_{2 \mathrm{e}} \\
\text { day }^{-1} \text { ) }\end{array}\right. \\
\end{array}$ & $\begin{array}{c}\begin{array}{c}\text { MCHP,heat } \\
\text { (tons } \mathrm{CO}_{2 \mathrm{e}} \\
\text { day }^{-1} \text { ) }\end{array} \\
\end{array}$ & $\begin{array}{c}\mathrm{MC}_{\text {fer }} \\
\text { (tons } \mathrm{CO}_{2 \mathrm{e}} \\
\text { day }^{-1} \text { ) } \\
\end{array}$ & $\begin{array}{c}\mathrm{MELCO}_{2 \mathrm{e}} \\
\left(\begin{array}{c}\text { tons CO} \\
\left.\mathrm{day}^{-1}\right)\end{array}\right. \\
\end{array}$ & $\begin{array}{c}\text { TOTAL } \\
\left(\begin{array}{c}\text { tons CO } \\
\left.\text { day }^{-1}\right)\end{array}\right. \\
\end{array}$ & $\begin{array}{c}\text { TOTAL } \\
\text { (tons CO } \mathrm{CO}_{2 \mathrm{e}} \\
\text { year }^{-1} \text { ) } \\
\end{array}$ \\
\hline Çerkezköy & 0.96 & 0.39 & 0.08 & 1.41 & 2.84 & 1035.8 \\
\hline Çorlu & 2.91 & 1.19 & 0.24 & 4.26 & 8.60 & 3140.1 \\
\hline Ergene & 1.68 & 0.69 & 0.14 & 2.46 & 4.96 & 1812.2 \\
\hline Hayrabolu & 4.79 & 1.96 & 0.40 & 7.03 & 14.18 & 5175.5 \\
\hline Kapaklı & 1.57 & 0.64 & 0.13 & 2.31 & 4.66 & 1700.6 \\
\hline Malkara & 5.19 & 2.13 & 0.43 & 7.61 & 15.36 & 5607.2 \\
\hline Marmaraereğlisi & 1.84 & 0.76 & 0.15 & 2.71 & 5.46 & 1992.7 \\
\hline Muratlı & 12.01 & 4.92 & 1.01 & 17.63 & 35.57 & 12982.3 \\
\hline Saray & 1.61 & 0.66 & 0.13 & 2.37 & 4.77 & 1741.6 \\
\hline Süleymanpaşa & 3.03 & 1.24 & 0.25 & 4.45 & 8.99 & 3279.6 \\
\hline TOTAL & 35.59 & 14.58 & 2.98 & 52.24 & 105.39 & 38467.6 \\
\hline
\end{tabular}

\section{Conclusions}

This research has been carried out by considering 100 or more cattle capacity farms with commercial biogas production potential in Tekirdağ province. It is possible to summarize the results obtained in the research as follows;

- $\quad$ There are 77 farms with more than 100 cattle capacity in Tekirdağ province. There are 23435 cattle in these farms. The number of animals in approximately $71 \%$ of these farms is below 200 .

- $\quad$ In these farms, a total of 470457.6 tonsyear $^{-1}$ liquid manure and 54667.2 tonsyear $^{-1}$ organic solid materials are produced. Methane production capacity of these manure has been calculated as $22466 \mathrm{Nm}^{3} \mathrm{day}^{-1}$. Energy value of this methane is 223.99 $\mathrm{MWhday}^{-1}$ and 81 756.4 $\mathrm{MWhyear}^{-1}$.

- If methane is used for heat purposes, $42512.48 \mathrm{MWhyear}^{-1}$ of useful heat energy will be provided. When using methane in the CHP unit, 28614.2 MWheyear $^{-1}$ of electrical energy and 19784.7 MWhyear $^{-1}$ of $^{-1}$ additional heat will be provided.

- Instead of long-term storage of manure, 12525.6 tons $\mathrm{CO}_{2 \mathrm{eyear}}{ }^{-1}$ less methane emission will be achieved in the use of methane production for heat purposes and 19400 tons $\mathrm{CO}_{2}$ eyear-1 when used in the CHP unit.

As seen in this research, it is determined that if biogas is obtained from the cattle manure that occurs in the farms in Tekirdağ province, there will be a significant amount of energy gain and the methane emission will decrease significantly. Many countries, especially Germany, are supporting farmers to turn to biogas production regardless of farm size, taking into account the important contributions of anaerobic fermentation to the methane attitude rather than obtaining energy from biogas. In our country, only $10 \%$ of the technical biogas potential is used (Yaldiz and Sezer, 2005; Tan, 2018). In our country, which is in an energy bottleneck, in order to spread biogas, which is a renewable energy source, the government must provide the support to enable enterprises to turn to biogas production without considering economic concerns. Considering the environmental contributions of biogas production, the importance of these supports increases. 


\section{References}

Anonymous (2017). State of biogas in the world. Clean Energy Solution Center, USA.

Anonymous (2019a). Enerji ve Tabii Kaynaklar Bakanlığı. https://www.enerji.gov.tr (erişim tarihi, 13.11.2019).

Anonymous (2019b). Tekirdağ Hakkında Bilgiler. https://tekirdag.csb.gov.tr/ilimiz-hakkinda-i-905 (erişim 18.11.2019).

Beil, M., Beyrich, W. (2013). Biogas upgrading to biomethane, The Biogas Handbook Science, Production and Applications, Ed: Wellinger A, Murphy J, Baxter D, Woodhead Publishing Series in Energy: Number 52, 367-377.

DECC (2013). Renewable Heat Incentive (RHI) - Increasing the use of low-carbon technologies. Available at: https://www.gov.uk/government/policies/increasing-the-use-of-low-carbon-technologies/supporting-pages/renewable-heat-incentive-rhi.

Dueblein, D., Steinhauser, A. (2011). Biogas from Waste and Renewable Resources, Second, Revised and Expanded Edition. WILEY-VCH Verlag GmbH \& Co. KGaA, 550 p, Weinheim, Germany.

Dumont, M., Luning, L., Yildız, I., Koop, K. (2013). Methane Emissions in Biogas Production, The Biogas Handbook Science, Production and Applications, Ed: Wellinger A, Murphy J, Baxter D, Woodhead Publishing Series in Energy: Number 52, $248-266$.

Frost, P., Gilkinson, S. (2010). First Year Performance Summary for Anaerobic Digestion of Dairy Cow Slurry at AFBI Hillsborough. Available at: http://www.afbini.gov.uk/ index/services/servicesspecialist-advice/renewable-energy-2012/re-anaerobic-digestion .htm

Harkin, T. (1997). An Overview of Animal Waste Pollution in America: Environmental Risks of Livestock and Poultry Production. U.S. Senate Committee on Agriculture, Nutrition, and Forestry, Washington, DC, USA.

Krich, K., Augenstein, D., Batmale, J.P., Benemann, J., Rutledge, B., Salour, D. (2005). Biomethane from Dairy Waste: A Sourcebook for the Production and Use of Renewable Natural Gas in California. Available from: http://www.biogas.psu.edu/pdfs/Biomethanefrom Dairysourcebook.pdf (erişim tarihi: 12.11.2019).

Lukahurst, C., Bywater, A. (2015). Exploring the Viability of Small Scale Anaerobic Digesters in Livestock Farming. Technical Brochure, IEA Bioenergy (eBook electronic edition), England.

Recebli, Z., Selimli, S., Özkaymak, M., Gonc, O. (2015). Biogas Production from Animal Manure. Journal of Engineering Science and Technology, 10(6): 722-729

Tan, F. (2018). Determination of The Biogas Potential From Animal Waste; Tekirdağ City Example. Journal of Scientific and Engineering Research, 5(1):92-96.

Yaldız, O., Sezer, S. (2005). Farklı büyüklükteki biyogaz tesislerinde sabit yatırım ve enerji üretimi maliyet hesabı. Tarım Makinaları Bilimi Dergisi, 1(3):213-220 